\title{
Profit Efficiency in EU FADN Farms under Different Types of Agriculture ${ }^{2}$
}

\begin{abstract}
The aim of the paper was to assess the profit efficiency in representative farms in FADN regions operating in various types of agriculture. For this purpose, clusters of FADN regions with relatively similar dominant types of agriculture were selected on the basis of their partial productivity indicators. Then, efficiency indicators were calculated for each region, using various types of DEA models. The data were adapted from FADN and covered the 2004 and 2015 period. On the basis of analysis conducted in the article, it was found that the farms located in Mediterranean regions were the most efficient. At the same time, in the cluster covering the regions with the most modern agriculture, the efficiency was at a very low level. Farms in most regions operated under the conditions of decreasing economies of scale, although the efficiency of scale itself improved. Moreover, in contrast to 2004, an increase in efficiency in relation to the best practice frontier was observed in 2015 .
\end{abstract}

Key words: efficiency analysis, DEA, FADN, farm income, models of agriculture

JEL Classification: Q12, Q14

\section{Introduction}

One of the main challenges in research concerning agricultural incomes in the European Union is the fact that, despite the mechanisms of the common agricultural policy, the conditions in which agricultural holdings in the EU operate are very diverse. This diversity is partly due to natural and environmental factors, but also to historical, social, cultural and economic ones. All these elements make up the model of agriculture observed in a given area (type, development stage). What model (type) of agriculture dominates in a given geographical or administrative region may influence the role of potential determinants shaping income in agriculture (Kryszak, 2017) and the level of income itself. However, the question arises whether representative farms operating in different types and models of agriculture differ also in terms of profit (income) efficiency, understood as the transformation of inputs in the form of various types of costs into the effect of profit (here: net income from an agricultural holding). It may be assumed that in regions where agriculture is of a more intensive nature, farm incomes are higher, but the efficiency of their creation may be lower, which results from the law of diminishing marginal returns. In other words, increasing expenditures (costs) no longer results in satisfactory increases in effects (income in this case).

The aim of this article is to assess profit (income) efficiency in clusters of EU FADN (Farm Accountancy Data Network) regions characterised by the dominance of different types (models) of agriculture. The article is organized as follows: the next section includes

\footnotetext{
1 MA, Department of Macroeconomics and Agricultural Economics, Poznan University of Economics and Business, al. Niepodległości 10, 61-875 Poznań, e-mail: lukasz.kryszak@ue.poznan.pl; https://orcid.org/0000-0001-8660-9236

${ }^{2}$ This publication is part of a project funded by the National Science Centre (Poland) awarded by decision number: UMO-2016/23/N/HS4/03453
} 
a discussion of classifications of types, models and stages of development of agriculture, indicating differences between these concepts and the theoretical basis for the approach used to determine types of agriculture for the purposes of this study. Next, the methodology of the research is presented, taking into account the clusters analysis and efficiency studies using the DEA method. Then the results of the conducted analysis are presented. The paper ends with major concluding remarks.

\section{Types and models of agriculture in the EU - literature review}

The formation of an agricultural model (type) in a given area and in a given historical period is connected with the theory of structural changes, understood as changes in the relative weights of the individual aggregates in the economy. In agriculture, structural changes most often concern the number and average size of farms. Goddard et al. (1993) listed eight factors which shape these changes. These are: price relations, available technology, human capital (including competences of the farmers), demographics, possibility of employment outside agriculture, economic growth rate, institutional environment and economic policy of the state.

However, the relationships among the factors of production (resource relations), which are determined by their relative prices, play a particular role. Indeed, a relative increase in the cost of labour leads to a decline in its use in favour of capital or land, which in the long run stimulates changes in agricultural resource relations (Hayami and Ruttan, 1970). Those relations, on the other hand, are the basic, though not the only, determinants of productivity. Both theoretical models and empirical studies (cf. Baer-Nawrocka and Markiewicz, 2013; Kierepka, 2006) confirm that favourable resource relations coincide with high productivity rates.

Structural changes of an economic nature in the context of changing social, technological and environmental conditions have become the starting point for interdisciplinary research concerning the classification of the history of agriculture, as well as its types and models of development. These three terms, although sometimes used interchangeably, in fact refer to separate concepts.

Historical classifications (eras, stages of development) usually take a broad time perspective and try to determine the basic characteristics of the way agriculture functioned in a given historical epoch (cf. Zegar, 2012; Jepsen et al., 2015). Types of agriculture are, in turn, specific forms of functioning of the sector as a whole, or ways of carrying out agricultural activities by individual holdings, taking into account the production methods used and the approach taken to achieve economic, social and environmental objectives. Zegar (2012) lists the following types of agriculture: natural, traditional, industrial, integrated, organic, ecological and sustainable. They differ in the role played by nonproductive (including environmental and cultural) functions of agriculture, but also in the use of particular production factors (especially labour and capital). Agricultural development models, on the other hand, synthetically show the evolution of the functioning of the agricultural sector or farms in a given area and identify the factors which determine and stimulate this evolution. Thus, in contrast to the types, the emphasis is on the dynamic aspect rather than on the characteristics of the specific methods of agricultural activity (cf. typologies by Ruttan and Hayami, 1972 or Herlmemann and Stamer, 1963). Nevertheless, especially in the latter typology, the basis for the distinguishing phases of agricultural 
development are the changes in the relative use of production factors. In the case of the EU, the existence and development of the so-called European Agricultural Model is also often pointed out. Although it is possible to list several features which distinguish European agriculture from that in other regions of the world (Kowalczyk and Sobiecki, 2011), its high heterogeneity is usually stressed (Sortino and Chang Ting Fa, 2009), which is visible mainly in the regional perspective.

The above literature review, by necessity rather cursory, indicates that the basic distinguishing feature of both agricultural development models and types are the relations among factors of production (resource relations) and productivity of these factors. Changes in the resource relations and productivity of agriculture in a given region can be stimulated by appropriate policies, but as a general rule they occur quite slowly, hence the differences in this respect among FADN regions remain significant. Thus, it seems appropriate to determine the clusters of FADN regions with the dominance of different types of agriculture on the basis of average productivity indicators and/or resource relations.

\section{Data and methods}

In the first stage of the study, a cluster analysis was carried out to classify representative farms in FADN regions into relevant clusters. The use of cluster analysis as a research method should be accompanied by a verification of compliance with the assumptions. First of all, the collinearity among variables used is evaluated, then outlier observations are identified and, finally, the statistical significance of differences in values of variables between particular clusters is evaluated (Stanisz, 2007). According to theoretical assumption, the capital to labour ratio determines the productivity of labour, while the relation of capital to land determines the productivity of land. These pairs of variables are strongly correlated. Therefore, a cluster analysis was finally carried out on standardized values of the following variables:

- labour productivity - the ratio of output at constant prices to labour input in AWU (Annual Work Units)

- capital productivity - the ratio of output at constant prices to capital input at cost terms (sum of intermediate consumption, depreciation, interest and rents)

- land productivity - the ratio of output at constant prices to the total land input in hectares.

The values of the correlation coefficient between these variables did not exceed 0.5 while the values of the variance inflation factor did not exceed 2, which is consistent with the most restrictive versions of the rule of thumb (Chatterjee and Hadi, 2015). Only values in nominal prices are available in the FADN database. They were adjusted to constant prices using relevant price indices from Eurostat (output of agricultural industry price index, total intermediate consumption price index, fixed capital consumption price index, Harmonised Index of Consumer Prices). At the same time, for regions with currencies other than euro, figures have been converted at the fixed exchange rate (2004) or in the year of the country's entry into the euro area.

All FADN regions in the EU-25 group of countries, i.e. members of the community in 2004 were intended to be included in the analysis of clusters. However, due to the need to eliminate outlier observations, Cyprus, Malta, the city of Hamburg, the Balearic Islands, the 
Canary Islands and Denmark were eventually left out. Therefore, 110 FADN regions were eventually included in the analysis. The makeup of clusters was determined on the basis of average values of the abovementioned partial productivity indicators for the years 20042015, using the Ward method with Euclidean distances.

In the second step, the efficiency was calculated. In literature one may find different concepts of efficiency, however in this paper the profit (income) efficiency concept is used where the income serves as the output variable measure (cf. Ali and Flinn, 1989). Indicators-based, parametric or non-parametric methods may be used to assess an entity's financial efficiency (Czyż-Gwiazda, 2013). Traditional ratio analysis can be used for the financial aspects of the farm operation, but it has the disadvantage of treating each dimension of the assessment separately ${ }^{3}$. Parametric and non-parametric methods allow to take into account many effects and inputs at the same time. Parametric methods (e.g. SFA Stochastic Frontier Approach) require making assumptions about the form of the production function. This study uses a non-parametric method of efficiency assessment DEA (Data Envelopment Analysis) - using constant return of scale (CRS) and variable return to scale (VRS) assumptions ${ }^{4}$. SFA and DEA belong to "frontier methods". In this paper both possibilities of the DEA model were tested: output-oriented and input-oriented. The main advantage of the DEA method is that, unlike SFA, it does not require an a priori assumption of the form of the production function, which also facilitates the process of interpretation of results (Czyż-Gwiazda, 2013). It should be stressed that the efficiency in the DEA method is understood in a relative way, i.e. in relation to the best practice frontier in each case. This means, among other things, that the assessment of the efficiency of a given entity depends on which group of entities is included in the study. Moreover, a distinction should be made between the concept of effectiveness and efficiency. Effectiveness is a measure of achieving an goal (in this case, the highest possible income). A high-performance farm is effective, but not necessarily efficient, because it may, for example, be able to achieve the same result at a lower cost or with a higher result at the same cost. The definition of efficiency which constitutes the starting point for the research presented in this paper is the one taken from the financial field. According to that definition, efficiency is "the ratio of outputs to inputs, where both components are expressed in financial terms; the outputs are: the economic result, an increase in the value of assets or a decrease in liabilities, or possibly a cash balance; inputs may include: costs, liabilities, owner equity and expenses" (Głodziński, 2014). The drawbacks of the DEA method include the sensitivity of the results to atypical observations and the fact that the number of units assessed as fully effective is usually quite high (Guzik, 2009), which makes it difficult to identify a narrow group of "leaders" as reference for other entities.

The DEA method uses the programming procedure to assess the efficiency of decision making units (DMU). The efficiency of DMU is shown as a technical efficiency index expressed as a weighted sum ratio of outputs to the weighted sum of inputs:

$$
\theta=\frac{\sum_{r=1}^{R} y_{r} \lambda_{r}}{\sum_{n=1}^{N} x_{n} \lambda_{n}}
$$

\footnotetext{
${ }^{3}$ Synthetic indicators, such as the Hellwig method or the TOPSIS method, are means of reducing this disadvantage.

${ }^{4}$ More information on the DEA method can be found in Ćwiakała-Małys and Nowak (2009).
} 
Where: $y_{r}$ is unit value of $r$-output; $x$ - unit value of $n$ - input; $\lambda_{r}$ and $\lambda_{n}$ are the weights of outputs and inputs; $r$ - number of outputs, $n$ - number of inputs. Determining effectiveness in the DEA method consists of solving a linear programming problem in which the decision variables are $\lambda j$ intensity weights and efficiency is reflected in the objective function. Determining the optimal value of the objective function is related to the determination of intensity weights, which the ineffective unit is indicated by a set of reference objects (so-called benchmarks) (Masternak-Janus and RybaczewskaBłażejowska, 2016).

The basic form of the DEA model is an input-oriented model with constant return to scale assumptions. The dual form of the model can be presented as follows:

$$
\begin{gathered}
\theta \rightarrow \min \\
\sum_{j=1}^{J} y_{j r} \lambda_{j} \geq y_{j r} \\
\sum_{j=1}^{J} x_{j n} \lambda_{j} \leq x_{j n} \theta \\
\lambda_{j} \geq 0
\end{gathered}
$$

Where: $\theta$ - efficiency ratio of DMU; $\lambda$ - intensity weights; $j=1, \ldots, J, r=1, \ldots, \mathrm{R}, n=1$, $\ldots, \mathrm{N}$. This basic form of the model was then subject to numerous modifications.

The DEA method is widely used, also in agricultural research. A review of studies using the DEA method, including more than 10,000 articles published between 1978 and 2016 (Emrouznejad and Yang, 2018), shows that agriculture was ranked first among the most popular research areas in which the DEA method was applied between 2015 and 2016, with agricultural output being the most common measure of the effect, while input measures are production factors (expressed either as cost or materially) (cf. SmeddzikAmbroży, 2010; Lissitsa et al., 2007). Among the studies that take into account the income aspect one can mention Sobierajewska's work (2009).

In this paper the efficiency was studied using values expressed in monetary terms. The output is the net farm income (SE42), while inputs are different cost categories: total specific costs (SE281), total farming overheads (SE336), depreciation (SE360) and costs of total external factors (SE365). Efficiency results are given for 2004 and 2015. The survey was therefore carried out for the year in which 10 countries joined the EU (15 new FADN regions) and also for the year in which the Common Agricultural Policy 2007-2013 was completed. An analysis of the effectiveness in these two sub-periods will therefore allow an assessment of changes in relative efficiency and the type of scale effects in which representative farms operated. 


\section{Results}

As a result of the cluster analysis, 4 clusters of regions were obtained, varied in terms of average productivity of particular production factors (cf. Figure 1). Cluster A consists of only 7 regions: the Netherlands, Flanders and five regions of northern Italy. It is an "outlying" group due to the extremely intensive nature of agriculture in these areas, which results in very high productivity values of the land factor. Cluster B comprises 36 regions. It is made up of Walloon, Luxembourg, the regions of Northern and Central Germany, Northern and Central France, the British, Swedish and two Finnish regions. Cluster C includes 32 regions. Those are the Italian regions not forming part of Cluster A, one Portuguese region, most of the Spanish regions and all 4 Greek regions. Conversely, Cluster D comprised 35 regions. It includes the regions of southern Germany and France, Austria, Ireland, 3 Portuguese regions, 2 Finnish regions and the regions of the countries that joined the EU in 2004. Baráth and Fertö (2017) carried out a clustering on the basis of other variables characterising the conditions for agricultural production (the share of primary agricultural products and secondary activities in total output, and variables accounting for environmental conditions: mean annual temperature and average precipitation). However, as mentioned in the literature review, partial productivity indicators may constitute a proxy for the conditions of the functioning of agriculture. The mentioned authors obtained 5 clusters of Member States in the EU, but the obtained groups reflected in part the division used in this article (e.g. "Mediterranean" cluster).

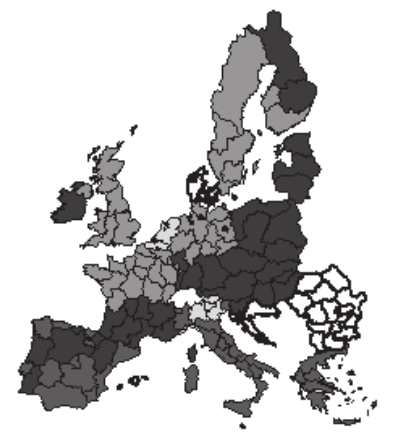

Fig. 1. Clusters of FADN regions with similar factors productivity

Source: Author's own elaboration based on FADN Database.

Statistical significance of differences between average values of variables in particular clusters was determined with the use of a non-parametric ANOVA equivalent - KruskalWallis test ${ }^{5}$. This test should be used if there are more than 2 clusters in the analysis and if, at the same time, the assumption about normal distribution for a given variable in all subgroups is not fulfilled. The statistical significance of differences was tested for both the three variables which were used to construct the clusters and the three resource variables

\footnotetext{
${ }^{5}$ It should be noted that the test itself only informs about the overall difference in the averages, whether it is statistically significant or not. In practice, however, it may occur that the test gives the desired value, but the final value was affected by differences between the averages in two clusters only, whereas the difference between Clusters B and D, for example, may not be significant.
} 
that were ultimately not included in the procedure. The test results showed that the hypothesis that means are equal could be rejected for all variables with a very high degree of confidence.

Average values of particular variables as well as relatively high values of coefficients of variation in the identified clusters indicate that significant differences in the economic conditions of the functioning of agriculture between regions in the EU persist (cf. Table 1).

Table 1. Mean values of productivity and resource relations variables

\begin{tabular}{l|cccccccc}
\hline \multirow{2}{*}{ Variable } & \multicolumn{4}{c}{ Mean (in thousands of euro) } & \multicolumn{5}{c}{ Coefficient of Variation (\%) } \\
& A & B & C & D & A & B & C & D \\
\hline labour productivity & 74.0 & 92.8 & 33.0 & 39.5 & 52.7 & 16.1 & 29.6 & 51.9 \\
capital productivity & 1.95 & 1.15 & 2.05 & 1.26 & 27.2 & 8.7 & 20.3 & 15.1 \\
land productivity & 8.0 & 1.8 & 2.5 & 1.4 & 22.3 & 35.7 & 42.9 & 51.9 \\
capital/labour ratio & 45.7 & 80.8 & 16.9 & 32.2 & 77.1 & 14.9 & 38.6 & 54.5 \\
land/labour ratio & 9.83 & 57.48 & 16.78 & 30.52 & 54.7 & 40.6 & 61.0 & 49.3 \\
capital/land ratio & 4.1 & 1.4 & 1.2 & 1.1 & 35.9 & 32.5 & 43.9 & 49.4 \\
\hline
\end{tabular}

Source: Author's own calculations based on FADN Database.

Cluster A is dominated by a type of agriculture which can be described as extremely intensive. Farms in this group of regions are relatively small in terms of agricultural area, but very high capital expenditure is applied, which translates into high land and labour productivity values. In contrast to Cluster B, Cluster A has such favourable production conditions which, combined with the predominance of production types with a high rate of return, result also in high capital productivity. Referring to the Zegar's typology, agriculture in this cluster is close to the modern concept of integrated agriculture.

In Cluster B, which covers the majority of the most developed areas of north-western Europe, modern industrial agriculture dominates. Farms in this group of regions are usually large or very large. Very high capital expenditure is used (mainly in relation to labour), which results in high labour factor productivity values. However, due to unfavourable climatic conditions for production (especially in Scandinavian regions), the productivity of the land factor is lower there, not only in comparison to Cluster A, but also to $\mathrm{C}$. The lowest value of capital productivity compared to other clusters, amounting to 1.15 , is a symptom of a gradual decrease in the effectiveness of intensification strategies in agriculture. This means that for every euro spent in Cluster B, only 1.15 euro of the value of agricultural production was obtained on average.

Agriculture in Cluster $\mathrm{C}$ regions can be described as the Mediterranean type. On average, capital expenditure on these farms is among the lowest. Moreover, relatively small farms characterised by relatively high labour input are predominant. At the same time, natural conditions allow for specific production orientations (e.g. olive groves), which enables farmers to obtain significant revenues from sales without the need to own large areas and expensive capital resources. Thus, the focus is on high land productivity values and the highest capital productivity values compared to other clusters.

It is difficult to unambiguously define the dominant type of agriculture in Cluster D. In most regions of this cluster large farms are prevalent, but they are much less equipped with 
the capital factor in relation to farms in Clusters A and B (especially in terms of capital to labour ratio). The unfavourable relationship between the factors of production, combined with some technological lagging, leads to the extensification of production and relatively low labour productivity values. Despite the lower intensity of management in comparison to Cluster B, the productivity of capital in Cluster D is only slightly higher. It is unclear whether farms in Cluster D could still benefit from the intensification path. Nowadays, referring to the typology of Jepsen et al. (2015), agriculture in these areas is often dual in nature. Large, market-oriented holdings are accompanied by numerous smaller, subsistence farms.

In the light of previous considerations on the essence of efficiency, the question arises whether farms achieving higher productivity of production factors are also more efficient at transforming inputs (here: costs) into an effect in the form of income from an agricultural holding. For this purpose, the profit (income) efficiency of agricultural holdings in 2004 and 2015 was examined. The aim, however, was not to analyse the changes over time (in such case the Malmquist index should be used) but to assess the efficiency and to check whether the farms in the regions which were most efficient in 2004 stood out in this respect in 2005 as well. To begin with, descriptive statistics of variables used to construct DEA models are presented.

Table 2. Mean values of variables used in DEA analysis

\begin{tabular}{|c|c|c|c|c|c|c|c|c|}
\hline \multirow{2}{*}{ Variable } & \multicolumn{4}{|c|}{ Mean (in thousands of euro) } & \multicolumn{4}{|c|}{ Coefficient of Variation (\%) } \\
\hline & A & $\mathrm{B}$ & $\mathrm{C}$ & $\mathrm{D}$ & A & $\mathrm{B}$ & $\mathrm{C}$ & $\mathrm{D}$ \\
\hline & & & & & 004 & & & \\
\hline Total specific costs & 44.4 & 74.4 & 12.9 & 22.3 & 81.1 & 82.0 & 54.5 & 80.2 \\
\hline Total farming overheads & 19.7 & 61.3 & 5.3 & 19.2 & 114.4 & 95.0 & 59.0 & 82.8 \\
\hline Depreciation & 14.5 & 31.6 & 4.4 & 10.9 & 72.9 & 65.0 & 66.2 & 72.4 \\
\hline Total external factors & 16.5 & 50.1 & 4.3 & 11.2 & 116.9 & 133.7 & 75.1 & 106.8 \\
\hline \multirow[t]{2}{*}{ Farm net income } & 31.9 & 33.9 & 19.8 & 17.3 & 41.2 & 49.6 & 42.4 & 51.3 \\
\hline & \multicolumn{8}{|c|}{2015} \\
\hline Total specific costs & 72.7 & 118.8 & 19.3 & 45.2 & 101.5 & 70.2 & 52.9 & 115.0 \\
\hline Total farming overheads & 29.7 & 78.1 & 10.2 & 32.2 & 108.7 & 63.5 & 53.2 & 91.0 \\
\hline Depreciation & 18.1 & 42.6 & 5.0 & 17.5 & 102.8 & 55.4 & 52.2 & 97.4 \\
\hline Total external factors & 22.4 & 59.6 & 8.0 & 20.8 & 122.4 & 120.8 & 65.0 & 151.8 \\
\hline Farm net income & 47.7 & 34.5 & 26.0 & 21.9 & 52.0 & 34.7 & 38.8 & 46.5 \\
\hline
\end{tabular}

Source: Author's own calculations based on FADN Database.

In both sub-periods, significantly higher values of the effect in the form of net income from agricultural holdings were observed in Clusters A and B as compared to Clusters C and D. At the same time in Clusters A and B significantly higher inputs (costs) were recorded, in particular fixed costs. At the same time, a significant level of differentiation of the analysed variables in particular clusters was observed. It particularly concerned the costs of external factors, which can be treated as a proxy of advancement of agricultural development processes. In areas where agriculture is relatively developed, external services 
are more frequently used. Moreover, it should be added that differences in the level of farm income and costs result partly from the size of farms. Especially in Cluster B, relatively large farms dominate.

In 2004, the highest efficiency values were recorded on average in farms located in the regions belonging to Cluster $\mathrm{C}$ (Mediterranean type). This applies both to the model with constant returns to scale and to the input-oriented model with variable return to scale assumption. In the case of the output-oriented model, slightly higher efficiency was achieved in the Cluster A regions. On the basis of the calculated efficiency indicators, it can be concluded that in the case of Cluster $\mathrm{C}$ regions, achieving full efficiency would require a proportional reduction of inputs on average by $34 \%$, without prejudice to the value of the effect (income). In turn, in the case of Cluster B, the inputs would have to be reduced by as much as $76 \%$. From the perspective of the output-oriented model, it can be said that to achieve full efficiency from given inputs, the effect (income) would need to be increased on average by ca. $31 \%$ in the case of Clusters A and by ca. 51\% and 54\% in the case of Clusters B and D, respectively. Therefore in 2004, relatively high profit (income) efficiency was achieved by farms in the "Mediterranean" cluster, i.e. in regions where labour productivity was quite low, but due to favourable climatic conditions there was no need to incur high capital costs, as well as in regions with extremely intensive agriculture (Cluster A), where high labour productivity values were achieved at relatively high inputs. In other words, relatively high levels of profit efficiency were accompanied by high levels of capital productivity.

Regarding the problem of the scale of production, it should be noted that particularly large differences between the average efficiency levels of models with constant and variable returns scale were observed for Cluster D (input-oriented model) and Cluster B (output-oriented model). In the case of Cluster B, the problem was that the scale of production was too great (in the light of the input-oriented model, 32 out of 36 regions were operating under conditions of decreasing economies of scale, while from the perspective of the output-oriented model, all 36 regions were operating under conditions of decreasing economies of scale). This means that a t-fold increase in outlays led to less than a $t$-fold increase in effects. On the other hand, in Cluster D, which largely covered the regions of the so-called new Member States, the scale of production was much more problematic (farms operated in the conditions of growing economies of scale in an input-oriented model in 16 out of 34 regions, and 4 regions operated in an output-oriented model). When interpreting the scale efficiency index in the case of input-oriented models, it can be said that adjusting the scale of activity of households to the optimal one would result in a reduction of costs in Cluster $\mathrm{C}$ by only $11 \%$, whereas in Cluster $\mathrm{B}$, due to the low scale efficiency, it would be possible to reduce costs by $31 \%$. It can be concluded that in areas where agriculture is relatively highly developed (Cluster B), symptoms of depletion of income growth paths, consisting of intensification understood in terms of growing costs, were already observed in 2004. Although labour productivity and profitability associated with it were high in these regions, low profit efficiency was also observed, which was largely related to the fact that production was too high.

On the basis of the DEA models, it was found that the representative holdings which were fully efficient in both constant and variable returns to scale models were located in 5 regions. These were Liguria (Northern Italy - Cluster A) and the four Cluster C regions: Madrid, Valencia, Calabria and the Greek region of Ipiros-Peloponissos-Nissi Ioniou. In models with variable returns to scale assumptions, farms in Andalusia and Galicia (Cluster C), Champagne (Cluster B), Lithuania, Małopolska and Pogórze (D), as well as Lombardy 
(A) were also efficient. The last two are particularly interesting, as in the VRS models the efficiency of farms in these regions is 1, whereas in the CRS models it is only 0.304 and 0.322 , respectively, which indicates an inadequate scale of production, which in the case of Lombardy may be too high, and in Małopolska and Pogórze - far too low.

Table 3. Mean DEA results in delimited clusters (2004)*

\begin{tabular}{l|cccc}
\hline \multicolumn{1}{c|}{ Model } & A & B & C & D \\
\hline CRS & 0,398 & 0,160 & 0,597 & 0,279 \\
VRS input & 0,534 & 0,236 & 0,664 & 0,431 \\
Scale efficiency & 0,778 & 0,691 & 0,892 & 0,711 \\
VRS output & 0,694 & 0,492 & 0,685 & 0,457 \\
Scale efficiency & 0,544 & 0,331 & 0,846 & 0,630
\end{tabular}

* Slovakia was excluded due to the negative value of the output (income)

CRS - Constant returns to scale; VRS- Variable returns to scale

Source: Author's own calculations based on FADN Database.

In 2015, farms in five FADN regions were again fully efficient with both VRS and CRS models. These include Calabria and the Valencian Community (as in 2004), as well as Sardinia, Galicia and the Azores and Madeira. When it comes to efficiency in VRS models, the value of 1 was achieved by farms in 15 regions, compared to 11 in 2004. In addition to the five listed above, there were: Andalusia, Emilia-Romagna, Ipiros-Peloponissos-Nissi Ioniou, La Rioja, Piedmont, Thessalia and Sterea Ellas-Nissi Egaeou-Kriti (Cluster C), Lombardy (A), Małopolska and Pogórze and Slovenia (D). The average efficiency ratios decreased slightly only in Cluster B. In the other clusters (especially A) they increased quite significantly. On the basis of this information, it is not possible to determine whether the efficiency in individual regions has increased, but it can be assessed that there is a convergence in the efficiency, i.e. in the case of most regions the profit (income) efficiency of agricultural holdings is now closer to the value of 1 , which means that it is closer to the best practice frontiers. As in 2004, the highest average relative efficiency was recorded in Cluster C, followed by Clusters A, D and B.

Table 4. Mean DEA results in delimited clusters (2015)*

\begin{tabular}{l|cccc}
\hline \multicolumn{1}{c|}{ Model } & A & B & C & D \\
\hline CRS & 0,602 & 0,158 & 0,721 & 0,364 \\
VRS input & 0,665 & 0,207 & 0,813 & 0,455 \\
scale & 0,875 & 0,830 & 0,893 & 0,821 \\
VRS output & 0,809 & 0,408 & 0,812 & 0,525 \\
scale & 0,718 & 0,407 & 0,886 & 0,672 \\
\hline
\end{tabular}

* Thueringen was excluded due to the negative value of the output (income)

CRS - Constant returns to scale; VRS- Variable returns to scale

Source: Author's own calculations based on FADN Database.

Apart from Cluster C, the difference in average efficiency ratios between CRS and VRS models was lower in 2015 than in 2004. Therefore, economies of scale improved, which 
means that the scale of activities on agricultural holdings in the various regions are closer to the optimum. Low values of efficiency in Cluster B are confirmed by previous theses about gradual exhaustion of the industrial income growth path in agriculture, which is also a result of the law of diminishing marginal returns. As in 2004, farms in all 36 regions were operating under conditions of decreasing economies of scale (according to the output-oriented model). Farms in 9 regions (mainly Scandinavia) operated under conditions of increasing economies of scale in the light of an input-oriented model, but the development of agriculture in these areas faces climatic barriers. As far as Cluster D is concerned, farms in 23 regions (including all Polish regions) functioned under conditions of growing economies of scale (inputorientated model) and in 5 regions according to output-orientated model.

\section{Conclusions}

On the basis of the information included in this article the following can be stated:

- farms in the FADN regions of the European Union operate in highly diversified natural and economic conditions, which is reflected in different resource relations and differences in productivity of production factors. On the basis of the average values of these indicators, it is possible to determine the basic types of agriculture in the EU;

- there are significant differences in relative profit efficiency among the representative holdings in the various groups of regions. The farms in the Mediterranean regions were characterised by the highest efficiency in both research periods, which should be associated with favourable climatic conditions, enabling them to earn relatively high incomes at low cost;

- the lowest efficiency values were observed in farms in regions where industrial agriculture prevailed and where, among other things, high labour productivity values were observed. Deterioration of relative efficiency in this group indicates a decreasing potential of income growth through intensification of production understood in terms of input growth. This path may still be appropriate for farms in the "Polish"' cluster, where the level of intensification is relatively low,

- economies of scale on farms in the EU are improving, indicating that the scale of activity is better adapted to the optimal one, while farms in most regions are operating under conditions of decreasing economies of scale;

- a potential direction of further research on profit efficiency would be introducing additional elements to the analysis, such as the balance of cash flows or a decrease in liabilities of the holding on the outputs side, as well as debt or the use of equity on the inputs side.

\section{Literature}

Ali, M., Flinn, J.C. (1989). Profit efficiency among Basmati rice producers in Pakistan Punjab. American journal of agricultural economics, 71(2), 303-310.

Baer-Nawrocka, A., Markiewicz, N. (2013). Relacje między czynnikami produkcji a efektywność wytwarzania w rolnictwie Unii Europejskiej (Production potential and agricultural effectiveness in European Union countries). Journal of Agribusiness and Rural Development, 3(29), 5-16.

Baráth, L., Fertö, I. (2017). Productivity and convergence in European agriculture. Journal of Agricultural Economics, 68(1), 228-248. 
Chatterjee, S., Hadi, A.S. (2015). Regression analysis by example. John Wiley \& Sons.

Czyż-Gwiazda, E. (2013). Koncepcje pomiaru efektywności funkcjonowania organizacji-zastosowanie metody DEA w ocenie efektywności organizacji (Conceptions of organizational efficiency measurement -the use of the DEA method in evaluating the organization efficiency). Zarzadzanie $i$ Finanse, 1(1), 103-116.

Ćwiąkała-Małys, A., Nowak, W. (2009). Sposoby klasyfikacji modeli DEA (Classification of Data Envelopment Analysis models). Badania Operacyjne i Decyzje, 3, 5-18.

Emrouznejad, A., Yang, G.L. (2018). A survey and analysis of the first 40 years of scholarly literature in DEA: 1978-2016. Socio-Economic Planning Sciences, 61, 4-8.

Głodziński, E. (2014). Efektywność ekonomiczna-dylematy definiowania i pomiaru (Economic efficiency dilemmas in definition and measurement). Zeszyty Naukowe. Organizacja i Zarzqdzanie/Politechnika Ślaska, 73, 155-167.

Goddard, E., Weersink, A., Chen, K., Turvey, C.G. (1993). Economics of Structural Change in Agriculture. Canadian Journal of Agricultural Economics/Revue Canadienne D'agroeconomie, 41(4), 475-489.

Guzik, B. (2009). Propozycja metody szacowania efektywności instytucji non profit (The Proposition of an Estimating Method of Non Profit Institution Effectiveness). Roczniki Ekonomiczne Kujawsko-Pomorskiej Szkoty Wyższej w Bydgoszczy, (2), 75-92.

Hayami, Y., Ruttan, V.W. (1970). Factor prices and technical change in agricultural development: The United States and Japan, 1880-1960. Journal of Political Economy, 78(5), 1115-1141.

Herlemann, H.-H., Stamer, H. (1963). Rolnictwo w dobie technicyzacji. Państwowe Wydawnictwo Rolnicze i Leśne, Warszawa.

Jepsen, M. R., Kuemmerle, T., Müller, D., Erb, K., Verburg, P. H., Haberl, H., Björn, I. (2015). Transitions in European land-management regimes between 1800 and 2010. Land Use Policy, 49, 53-64.

Kierepka, M. (2006). Możliwości poprawy produktywności czynników wytwórczych w gospodarstwach rodzinnych (Possibilities of improving the efficiency of productive factors in family farms) Roczniki Nauk Rolniczych, Seria G, 92(2), 35-41.

Kowalczyk, S., Sobiecki, R. (2011). Europejski model rolnictwa-uwarunkowania ewolucji (European model of agriculture - determinants of evolution). Roczniki Nauk Rolniczych, Seria G, 98(3), 9-20.

Kryszak, Ł. (2017). Wybrane problemy rachunku dochodów rolniczych (Selected problems of agricultural income accounts). Roczniki Naukowe Stowarzyszenia Ekonomistów Rolnictwa i Agrobiznesu, 19(3), 168-173.

Lissitsa, A., Rungsuriyawiboon, S., Parkhomenko, S. (2007). How far are the transition countries from the economic standards of the European Union?: Measuring efficiency and growth in agriculture. Eastern European Economics, 45(3), 51-75.

Masternak-Janus, A., Rybaczewska-Błażejowska, M. (2016). Analiza efektywności innowacyjnej przedsiębiorstw przemysłowych w Polsce z wykorzystaniem metody DEA (Analysis of innovative efficiency of industria enterprises in Poland using the dea method). Innowacje w Zarzadzaniu i Inżynierii Produkcji, 1, 494-503.

Ruttan, V.W., Hayami, Y. (1972). Strategies for agricultural development. Food Research Institute, Stanford University.

Smędzik, K. (2010). Skala produkcji a efektywność różnych typów indywidualnych gospodarstw rolnych w Polsce z zastosowaniem modeli DEA (The Scale of Production and Its Influence on Effectiveness of Different Types of Individual Farms in Poland by Applying DEA Models). Roczniki Ekonomiczne KujawskoPomorskiej Szkoły Wyższej w Bydgoszczy, 3, 261-273.

Sobierajewska, J. (2009). Możliwości ekonomiczne polskich gospodarstw sadowniczych w latach 2004-2006 (Economic capabilities of Polish orchard farms in 2004-2006). Journal of Agribusiness and Rural Development, 3(13), 217-224.

Sortino, A., Fa, M.C.T. (2009). Endogenous Development and the European Model of Agriculture: Developing a Theoretical Framework. Economic Science for Rural Development, 19, 111-117.

Stanisz, A. (2007). Przystępny kurs statystyki: z zastosowaniem STATISTICA PL na przykładach z medycyny. Analizy wielowymiarowe (A comprehensive course in statistics. Multidimensional analyses). StatSoft.

Zegar, J.S. (2012). Współczesne wyzwania rolnictwa (The contemporary challenges of agriculture).Wydawnictwo Naukowe PWN

For citation:

Kryszak Ł. (2018). Profit Efficiency in EU FADN Farms under Different Types of Agriculture.

Problems of World Agriculture, 18(3), 196-207; DOI: 10.22630/PRS.2018.18.3.78 